\title{
Pavestolen har Europa som centrum igen
}

Thomas Harder

\section{Benedikt XVI vil modvirke den øgede sekularise- ring og afkristningen af Europa og har introduce- ret begrebet 'kristianofobi' om frygt for og had imod kristendom}

Da Benedikt XVI den 11. januar holdt sin traditionelle nytårstale (http://chiesa.espresso.repubblica. it/articolo/1346255?eng=y) til de ambassadører, der er akkrediteret ved Pavestolen, talte han til repræsentanter for 178 stater. I 1978, da den polske kardinal Karol Wojtyla blev valgt til pave og tog navnet Johannes Paul II, havde Pavestolen kun diplomatisk forbindelse med 84 stater. I løbet af Johannes Paul II's pontifikat steg antallet til 174, og i de snart seks år Benedikt XVI har været pave, er listen vokset med yderligere fire stater, blandt dem Rusland.

Pavestolen har desuden diplomatisk forbindelse med overnationale organisationer som EU, den Suveræne Militære Malteserorden og med den Palæstinensiske Befrielsesorganisation, PLO. Pavestolen har obser- vatørstatus i FN og Europarådet og er på forskellige måder repræsenteret i mange andre internationale organisationer og programmer. Med mange af disse stater og organisationer, og også med autonome enheder på lavere niveau, har Pavestolen indgået konkordater eller andre aftaler af forskellig art. I 2010 indgik Pavestolen fx en aftale med den tyske forbundsstat Niedersachsen om nogle katolske skolers juridiske status, med Bosnien-Hercegovina om sjælesorg for katolske medlemmer af landets væbnede styrker, og med den frie hansestad Hamborg om oprettelsen af et center for katolsk teologi og religionspædagogik ved Hamburgs Universitet.

Blandt de lande, som Pavestolen har diplomatisk forbindelse med, er også Taiwan. Her har man imidlertid ikke en nuntius, men kun 'en 
midlertidig chargé d'affaires', og man håber ad åre at kunne overføre repræsentationen til Beijing.

Folkerepublikken Kina er det største land, som Pavestolen ikke har diplomatisk forbindelse med. De øvrige er Kosovo, hvis internationale status endnu er omstridt, og 15 andre stater, hvoraf de fleste er asiatiske og en del har et islamisk befolkningsflertal.

I Afghanistan, Saudi-Arabien, Bhutan, Nordkorea, Maldiverne, Oman, Tuvalu og Vietnam er der ligesom i Folkerepublikken Kina ikke nogen officiel repræsentant for $\mathrm{Pa}$ vestolen, mens der i Comorerne, Mauretanien, Somalia, Brunei, Laos, Malaysia og Myanmar findes apostolske delegater, som repræsenterer Pavestolen over for de lokale katolske kirker, men som i modsætning til nuntierne ikke også er akkrediteret ved landenes regeringer.

Pavestolen og Vietnam har indledt officielle forhandlinger med henblik på at optage diplomatisk forbindelse, og de fleste af de øvrige lande har på forskellig vis uofficielle kontakter med Pavestolen. SaudiArabiens kong Abdallah var i november $2007 \mathrm{i}$ audiens hos paven, men derud over har Saudi-Arabien, hvor den katolske religion officielt er forbudt, ikke vist interesse for diplomatiske forbindelser med Pavestolen. Det samme gælder Maldiverne, som ligefrem forbyder katolske præster at rejse ind i landet, selv om Maldiverne modtager mange turi- ster fra katolske lande. Omkring 80 stater har en selvstændig ambassade ved Pavestolen, mens de øvrige har sideakkrediteret ambassadører i andre europæiske lande, idet Pavestolen ikke accepterer ambassadører, der også er akkrediteret Italien. Danmark genoptog i 1982 den diplomatiske forbindelse, som var blevet afbrudt af reformationen i 1536 , og siden har den danske ambassade i Bern også dækket Pavestolen. Samtidig med Danmark optog også Norge og Sverige diplomatiske forbindelser med Pavestolen.

\section{Suveræn stat siden 1922}

Det er værd at bemærke, at selv om Vatikanstaten har været en suveræn stat siden 1922, er det ikke den, der har diplomatisk forbindelse med omverdenen. Vatikanstaten hverken udsender eller modtager ambassadører. De 178 lande, der er omtalt ovenfor, har diplomatisk forbindelse med Paveembedet - Pavestolen eller, mere officielt, Den Hellige Stol.

Denne skelnen er mere end bare en kuriøs formalitet. Den afspejler en væsentlig forskel mellem Pavestolens udenrigspolitiske interesser, virkemidler og muligheder og dem, der kendetegner stater.

Pavestolen arbejder ikke for nationale interesser i gængs forstand den har ikke noget territorium at forsvare eller udvide, ingen grænsestridigheder eller etniske konflikter, ingen interesse i at sikre sig adgang 


\section{TEMA: RELIGION I INTERNATIONAL POLITIK}

til råvarer eller energikilder og ingen militær eller økonomisk magt at sætte bag sine krav eller ønsker. Pavestolens udenrigspolitik har til formål at beskytte kirken og de troende, at fremme kirkens virksomhed over hele verden og at arbejde for de sager og mål, som følger af kirkens religiøst funderede verdens- og menneskesyn.

I tidens løb har skiftende paver haft forskellige opfattelser af, hvad der var vigtigt, og hvordan udenrigspolitikken burde og kunne føres, men spørgsmål som fred, nedrustning, international sikkerhed og udvikling samt sociale, kulturelle og videnskabelige emner har altid haft høj prioritet. Pavestolens vigtigste udenrigspolitiske redskab er pavens person. Som åndeligt overhoved for over en milliard katolikker, cirka halvdelen af verdens kristne befolkning, og med 2000 års historie i ryggen, har paven en enestående status blandt verdens religiøse ledere.

'Den katolske kirkes udenrigspolitik' er imidlertid et både videre og vagere begreb end som så. Den føres nemlig ikke kun gennem pavens ord eller nuntiaturerne og de øvrige diplomatiske repræsentationer, men i høj grad også gennem de bispekonferencer, der står i spidsen for de nationale kirker rundt om i verden, og gennem de enkelte biskopper, som i de katolske lande er i nær kontakt med både myndigheder og civilsamfund og har adgang til medierne, samt gennem et meget stort antal mere eller mindre katolske lægmandsorganisationer, hjælpeorganisationer, missionsselskaber osv., som kan have ganske stor indflydelse dér, hvor de opererer.

\section{Økonomiske ressourcer}

Den italienske katolske kirke råder over ret store økonomiske ressourcer, som bl.a. bliver brugt til at understøtte de katolske kirker i den tredje verden, og en del af de italienske kirkeledere har derfor stor indflydelse i fx Latinamerika. Lægmandsorganisationen Sant'Egidioselskabet, som har base i Rom og giver sig af med hjælpearbejde i Italien og den tredje verden, har gennem et par årtier (med vekslende held) været meget aktiv som mægler i forskellige afrikanske konflikter, og takket være sine gode forbindelser til katolske italienske politikere har selskabet kunnet påvirke Italiens politik over for nogle af de lande, hvor det arbejder. Det er blot et par eksempler, der illustrerer, at Pavestolens udenrigspolitik bevæger sig ad mange forskellige kanaler, og at den ikke er ene om at formulere og føre 'den katolske kirkes udenrigspolitik'.

Johannes Paul II brugte sine mange rejser og sin betydelige evne til at kommunikere og til at komme tæet på de troende til at styrke pavens og pavemagtens centrale position i kirken på bekostning af de lokale niveauer og underskoven af katolske organisationer og til i højere grad 
end sine forgængere at gøre Pavestolen til en vigtig og dynamisk udenrigspolitisk aktør.

\section{Wojtylas magt i Øst}

Johannes Paul II's besøg i sit hjemland Polen i 1979, 1983 og 1987 bidrog i høj grad til at mobilisere og opmuntre oppositionen mod det kommunistiske regime i Polen og mod sovjetsystemet som helhed.

Johannes Paul II brød dermed den 'Østpolitik', som hans to forgængere Johannes XXIII og Paul VI havde ført: Efter Pius XII's (pave 1939-1958) markant antikommunistiske og vestligt orienterede udenrigspolitik søgte først Johannes XXIII (1958-1963) og siden Paul VI (1963-1978) at etablere og udbygge en dialog med de kommunistiske regimer for at finde konkrete måder, hvorpå man kunne bedre forholdene for de lokale katolske kirker og arbejde for afspænding mellem blokkene. Johannes XXIII foretog en række tilsyneladende spontane og symbolske gestus, som Paul VI systematisk byggede videre på ved at lade sin statssekretær ('regeringschef') Agostino Casaroli besøge Bulgarien, Tjekkoslovakiet, Ungarn, Polen og Jugoslavien for at forhandle om konkrete anliggender såsom bispeudnævnelser, kirkebyggeri, adgang til katolske præsteseminarier og katolske ordeners virksomhed.

I 1971 var Casaroli i Moskva for på Pavestolens vegne at undertegne af- talen om ikke-spredning af atomvåben, en handling, der i høj grad tjente til at markere, at Pavestolen var på talefod med begge supermagter, selv om den ikke havde formelle bånd til nogen af dem.

I 1975 undertegnede Pavestolen Helsingfors-slutakten, hvilket yderligere styrkede den katolske kirkes position som politisk aktør og synliggjorde dens engagement i nedrustning og menneskerettigheder. Trods det vanskelige forhold til USSR og de øvrige kommunistiske regimer lagde Paul VI vægt på at placere sig $\mathrm{i}$ en position mellem blokkene, hvorfra han kunne forholde sig kritisk til begge siders politik.

En anden vigtig fornyelse i Paul VI's pontifikat var hans åbning af Pavestolens politiske horisont mod ulandene. Kirkens perspektiv havde indtil da været udpræget eurocentrisk, men Paul VI gjorde Pavestolen til ulandenes fortaler og gjorde opmærksom på nord-syd-problematikken i FN-fora, i en række taler og ikke mindst i encyklikaen Populorum progressio (1967).

Encyklikaen forholdt sig meget kritisk til forholdet mellem den industrialiserede verden og ulandene og opfordrede i stærke vendinger de industrialiserede lande til at optræde retfærdigt og barmhjertigt over for ulandene. I 1968 åbnede Paul VI en konference i Bogotà, hvor alle Latinamerikas biskopper mødtes. Det understregede Pavestolens opmærksomhed på 'de unge 


\section{TEMA: RELIGION I INTERNATIONAL POLITIK}

kirker'. Samtidig udnævnte han flere biskopper fra den tredje verden til kardinaler - og gav dem dermed indflydelse på, hvem hans efterfølger skulle være - og gav prælater fra Afrika, Asien og Latinamerika embeder i den romerske kurie (kirkens 'centraladministration'). Disse udnævnelser brød de italienske gejstliges næsten-monopol på kurie-embederne, men dog ikke mere end at den forblev domineret af italienere i endnu et par årtier.

Johannes Paul II (1978-2005) bevarede Paul VI's opmærksomhed på den tredje verden, hvor den katolske kirke fortsat voksede hurtigt, samtidig med at den var i tilbagegang i Vesteuropa, men han ændrede fuldstændig kirkens perspektiv på Østeuropa og USSR. Johannes Paul II samarbejdede med vestlige ledere som Ronald Reagan og Margaret Thatcher i en grad, så nogle iagttagere spøgefuldt omtalte Vatikanet som et Nato-land, men det forhindrede ham ikke i at forholde sig lige kritisk til USSR's og Vestens optræden over for ulandene eller $i$ at kritisere Vestens gudløse materialisme og moralske relativisme, lige så stærkt som han kritiserede de kommunistiske regimers krænkelse af individets frihed og værdighed. Det indbragte ham kritik fra både konservative og liberale amerikanske medier, som beskyldte ham for at sætte USSR og USA på samme moralske niveau.

Johannes Paul II ønskede en afvik- ling af supermagternes rolle i den globale politik til fordel for et mere pluralistisk system, der, som han formulerede det, skulle bygge på "alle folks lighed og den nødvendige respekt for deres legitime forskelligheder".

I Østeuropa, og i særdeleshed i Polen, var Johannes Paul II's udgangspunkt et forsvar for religionsfriheden. Paven betragtede religionsfriheden som enestående blandt menneskerettighederne, fordi den vedrører menneskets forhold til Gud, men mente på den anden side ikke, at den kunne adskilles fra andre kulturelle, økonomiske, politiske og sociale rettigheder.

Kirken skulle ikke være en politisk institution, men en institution i samfundet, som sammen med andre institutioner - i Polen ikke mindst de faglige organisationer - skulle bekæmpe de kræfter, der truer menneskets værdighed.

\section{Efter Murens fald}

Efter Murens fald skiftede Johannes Paul II's udenrigspolitiske indsats delvis fokus. Hans kritik rettede sig nu mod den vestlige forbrugerkultur og mod den relativisme og det tab af religiøse værdier, som han betragtede som en trussel mod den vestlige kultur. Bioetikken - prævention, abort, stamcelleforskning, fosterdiagnostik, eutanasi - blev ud fra det religiøse princip om livets hellighed og ukrænkelighed fra undfan- 
gelsesøjeblikket til døden en af Pavestolens højt prioriterede udenrigspolitiske sager.

I forbindelse med FN's befolkningskonference i Kairo 1994 og konferencen om kvinders rettigheder i Beijing 1995 etablerede Pavestolen et samarbejde med en række muslimske lande, som delte den katolske kirkes modvilje mod abort.

Pavestolens udenrigspolitik er præget af en stærk pacifisme og vilje til at søge konflikter løst ved mægling og forhandling i internationale fora, først og fremmest FN. I 199091 stod pavestolen imidlertid temmelig alene med sin afstandtagen fra Vestens militære indsats mod Irak, som den pavelige 'udenrigsminister', den franske kardinal JeanLuis Tauran, betegnede som en 'ensidig angrebskrig', der "ville udgøre en forbrydelse mod freden og mod Geneve-konventionerne."

Pacifismen betyder dog ikke, at den katolske kirke ikke anerkender, at der kan være grund til at gå i krig - begrebet 'retfærdig krig' er oprindelig formulerer af den katolske kirke - og under konflikterne i Bosnien og Kosovo opfordrede kirken stormagterne til at skride til humanitær intervention for at afvæbne Slobodan Milosevics Serbien. Da det faktisk kom til luftangreb mod Beograd, valgte Pavestolen dog at tage afstand fra dem for ikke at skade forholdet til de ortodokse kirker, som man arbejdede, og stadig arbejder på at forbedre.

\section{Stærkt imod Irak krig}

Efter den 11. september 2001 støttede Pavestolen forsigtigt krigen i Afghanistan, men modsatte sig kraftigt invasionen i Irak. Denne stillingtagen skyldtes antagelig ikke bare kirkens grundlæggende pacifisme, men i høj grad også frygten for at udsætte de kristne mindretal i Irak og de øvrige arabiske lande for krigshandlinger eller repressalier.

Netop interessen for de kristne mindretal og for at beskytte og tilgængeliggøre de hellige steder i Israel giver Pavestolen et særligt perspektiv på konflikterne i Mellemøsten, hvor forholdet til Israel også af religiøse og historiske årsager er vanskeligt, og hvor kirken desuden er meget kritisk over for israelernes behandling af palæstinenserne.

Netop på dette meget følsomme område har kirkens og det kirkelige diplomatis optræden ikke altid været så klar og effektiv, som situationen ellers krævede: I april-maj 2002, da Fødselskirken i Betlehem i 39 dage var besat af bevæbnede palæstinensere og belejret af den israelske hær, havde kirkens folk svært ved at enes om, hvad de skulle mene om situationen, og deres uenighed kom meget tydeligt til udtryk over for omverdenen.

Et andet eksempel på mangelfuld koordination så man i 2004 under debatten om EU's forfatningstraktat, hvis artikel 51 omhandlede kirkernes forhold. Den pavelige 'uden- 
rigsminister', Tauran, udtalte sin støtte til artiklen, mens den italienske kardinal Camillo Ruini, der var pavens stedfortræder som Roms biskop og dermed den italienske kirkes primas, tog afstand fra den.

Da den tyske kardinal Josef Ratzinger blev valgt til pave i april 2005, overtog han en kirke, som stadig var i vækst i Afrika og Latinamerika, men i tilbagegang i Europa, og som desuden måtte forholde sig til et tiltagende vanskeligt forhold mellem Vesten og islam og til angreb på religionsfriheden overalt i verden.

Under Benedikt XVI er udnævnelsen af ikke-italienere og ikke-europæere til ledende stillinger i kurien fortsat, og iagttagerne deler sig nu mellem dem, der ser en velkommen internationalisering af kirkens centrale ledelse, og dem, der frygter, at kurien i virkeligheden er ved at blive mindre international. Ifølge denne tankegang opfattede de italienske prælater, der tidligere var næsten ene om at befolke kurien, ikke sig selv som repræsentanter for Italien, men som Kirkens mænd, hvorimod deres afløsere er sig mere bevidst, at de repræsenterer kirkerne i deres respektive hjemlande.

\section{Europa igen centrum}

Uanset om kurien vil udvikle sig i mere eller mindre international retning, virker det ret tydeligt, at Benedikt XVI i højere grad end sin forgænger igen har Europa i centrum af sit verdensbillede. Det gælder for Benedikt om at modvirke den sekularisering, som præger Europa, og som i stadig højere grad er ved at gøre troen til en privat sag, et personligt valg, som kun vedrører den enkelte og ikke har nogen plads i samfundet. Det er ikke kun et spørgsmål om at modarbejde lovgivninger, der strider mod kirkens lære, men om at finde veje til en genkristning af Europa, fra samfundets top til græsrødderne.

I en tale i 2006 sagde Benedikt XVI: "På den ene side må vi modsætte os et positivistisk diktatur, som udelukker Gud fra samfundslivet og den offentlige orden. På den anden side er det nødvendigt at byde oplysningstidens virkelige fremskridt velkommen - i særdeleshed menneskerettighederne og specielt den frie udøvelse af trosfriheden - og anerkende, at det er elementer, der også er afgørende for religionens egen ægthed og gyldighed."

Menneskerettighederne, og i særdeleshed trosfriheden, er det andet store fokuspunkt i Benedikt XVI's politik.

Den 20. december sidste år brugte han i en tale til kuriens medarbejdere udtrykket 'kristianofobi' - frygt for eller had til kristendommen som også anvendes af FN's Menneskerettighedskommission i Geneve på linje med 'islamofobi' og 'antisemitisme'. Talen var indrammet af efterårets blodige angreb på kristne $\mathrm{i}$ Irak og attentatet mod en koptisk 
kirke i Alexandria den 1. januar. Angrebene bekræftede for Vatikanet, at kristne er verdens mest forfulgte religiøse minoritet.

Paven vendte tilbage til emnet i årets nytårstale til det diplomatiske korps, som udelukkende handlede om religionsfriheden. Paven kritiserede uden diplomatiske omskrivninger Egypten, Saudi-Arabien, Pakistan, Kina, Nigeria, Cuba og flere andre lande for at krænke religionsfriheden. Paven opfordrede den pakistanske regering til at afskaffe landets blasfemilov, fordi den krænker religionsfriheden, og "tjener som påskud for at fremprovokere uretfærdigheder og vold mod religiøse mindretal."

Uden at nævne Indien ved navn henviste Benedikt til "lande i Syd- og Sydøstasien, som ellers her tradition for et fredeligt samfundsliv. Den omstændighed, at én bestemt religion har en særlig vægt i en nation, må aldrig medføre, at borgere, som tilhører en anden tro, bliver udsat for diskrimination i samfundslivet eller, endnu værre, at man tolererer vold imod dem. I den forbindelse er det vigtigt, at dialogen mellem religionerne fremmer en fælles bestræbelse på at anerkende hvert enkelt menneskes og hver enkelt befolkningsgruppes religionsfrihed."

Benedikt kritiserede også de lande i Vesten, "hvor man lægger stor vægt på pluralisme og tolerance, men hvor religionen marginaliseres mere og mere. Her betragtes religionen - enhver religion - som noget ligegyldigt, der ikke kommer det moderne samfund ved og måske ligefrem destabiliserer det, og man prøver med forskellige midler at forhindre den i at påvirke samfundslivet."

\section{Afkristningen af Europa}

Nytårstalens kritik rammer bredt, og der er ingen tvivl om, at bestræbelserne på at opmuntre de politiske og andre kræfter, som forsøger at modvirke 'afkristningen' af Europa, står højt på pavens dagsorden. Men der er heller ingen tvivl om, at den omhyggeligt afbalancerede tale, hvor kritikken af vestlige lande står over for de hårde ord om de muslimske, er udtryk for et ønske om ikke at støde de moderate muslimer fra sig.

Benedikt ønsker at udvise fasthed og at hævde de værdier, som han betragter som umistelige, men samtidig ønsker han også at række hånden frem mod de moderate kræfter i den muslimske verden, som man måske med tiden vil kunne samarbejde med.

Thomas Harder er cand.mag. $i$ italiensk og historie; adjungeret professor ved CBS, foredragsholder og forfatter til 25 bøger. 